\title{
Kinematics modeling analysis of the geostationary satellite monitoring antenna system
}

\author{
Quoc-Hoang Pham, Xuan-Hung Le, Manh-Tung Do, Tai-Hoai Thanh Nguyen, Hong-Phong Nguyen, \\ Tien-Trung Vuong, Van-Tuan Pham, Xuan-Bien Duong*
}

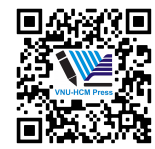

Use your smartphone to scan this QR code and download this article

Advanced Technology Center, Le Quy Don Technical University, 236 Hoang Quoc Viet, Bac Tu Liem, Hanoi, Vietnam

\section{Correspondence}

Xuan-Bien Duong, Advanced Technology Center, Le Quy Don Technical University, 236 Hoang Quoc Viet, Bac Tu Liem,

Hanoi, Vietnam

Email: duongxuanbien@|qdtu.edu.vn

History

- Received: 19-09-2020

- Accepted: 05/03/2021

- Published: 15/03/2021

DOI : 10.32508/stdjet.v4i1.770

\section{Check for updates}

\section{Copyright}

(c) VNU-HCM Press. This is an openaccess article distributed under the terms of the Creative Commons Attribution 4.0 International license.

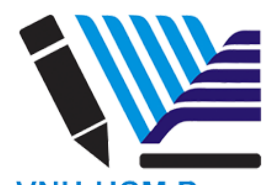

VNU-HCM Press

\begin{abstract}
The trend of scientific development in the future cannot fail to mention the great influence of the space field, but in the immediate future, the observational satellite systems are related to communication technology. In fact, in some countries with strong development of communication technology and space technology, the mechanical system of geostationary satellite monitoring antennas has certainly been thoroughly resolved. However, because of a specific technology, the sharing and transferring of design and manufacturing technology to developing countries is a great challenge. It is almost difficult to find published works related to mechanical design calculation and manufacture of geostationary satellite monitoring antenna systems. The problem of proactive grasping of technology, step by step autonomy in manufacturing technology of telecommunications equipment related to space technology has always been the goal of developing countries like Vietnam to limit technology dependence, minimizing technology transfer costs, ensuring national security. The first step in these problems is the autonomous construction of terrestrial transceivers such as geostationary satellite monitoring antennas.

This paper presents the kinematics modeling analysis of the mechanical system of the geostationary satellite monitoring antenna. Each component of the antenna system is assumed a rigid body. The mathematical model is built based on multi-bodies kinematics and dynamics theory. The DENAVIT-HARTENBERG (D-H) homogeneous matrix method was used to construct the kinematics equations. The forward kinematics problem is analyzed to determine the position, velocity, acceleration, and workspace of the antenna system with given system motion limits. The inverse kinematics problem is mentioned to determine the kinematics behaviors of the antenna system with a given motion path in the workspace. The numerical simulation results kinematics were successfully applied in practice, especially for dynamics and control system analysis of geostationary satellite antenna systems.
\end{abstract}

Key words: geostationary satellite, antenna system, modeling, kinematics

\section{INTRODUCTION}

Communication via satellite is the greatly important research result from the combination of the two fields of communication and space science ${ }^{1}$. The biggest advantage of this invention is its range of information transmission and low cost. An indispensable part of this satellite communication technology is the satellite antenna receiver and broadcasting system. Up to the present time, space technology is still a specific science that requires a very high level of scientific development. Therefore, in the world, only a few developed countries are able to develop this field such as Russia, USA, China, Japan ${ }^{1-7}$.

In Vietnam, autonomy in designing and manufacturing geostationary antenna systems based on the resources of domestic equipment is a necessary step to minimize the cost of applying satellite communication technology, reducing the depends on the level of supply from abroad, ensure national security, and onward mastering the design and manufacturing technology.

Mathematical modelling and kinematics analysis are the important steps in design and development of the antenna system for communications and monitoring of geostationary satellites. The motion characteristics and workspace of the antenna system are determined in details by solving the kinematics problem. A few works related to solving the kinematics and dynamics problems of geostationary satellite antenna systems were documented ${ }^{8-12}$. The basic construction of a satellite antenna was described by Bindi ${ }^{8}$. Basically, the geostationary satellite antenna system consists of a number of basic components which are base cluster, antenna shafts, and satellite pan cluster. The kinematics and dynamics model was also proposed and analyzed under the influence of heat and joint gineering and Technology; 4(1):705-713. 
error. A system of dynamic equations is built based on the finite element method and Lagrange II system of equations. The mathematical model describing the look angle of the geostationary satellite antenna mentioned by Ogundele ${ }^{9}$ is based on the use of two control station models. The adjustment model for the satellite antenna viewing angle was proposed Ogundele ${ }^{10}$. The working principles and classifications of the satellite surveillance antenna can be found in the report of Lida ${ }^{11}$. The geostationary satellite antenna system, called Horn Antenna, was designed and simulated by Shankar ${ }^{12}$; it was aimed to operate in the high-frequency regions. Researches related to the detailed design and manufacture of geostationary satellite antenna systems have not been well-documented, due to the security issues and design copyrights.

This paper presents the kinematics modeling analysis of geostationary satellite antenna systems. The system of kinematics equations of the antenna system is developed, for determination of the workspace through the limited values of joints. The inverse kinematics problem is analyzed to determine the kinematics behaviors of the antenna system with a given motion path in the workspace. The simulation results are obtained based on the numerical calculation methods. The results of this study have important meaning for the dynamic analyzing and the controller designing of the antenna system.

The rest of the paper is presented as follows. Firstly, the materials and methods are presented. The mathematical model and the kinematics equations that show the relationship between the joint variables and the pan cluster center of mass position of the antenna system in the workspace are mentioned. Next, the position, velocity, acceleration, and workspace of the antenna system are calculated. Then, some numerical simulation results of the inverse kinematics in order to determine the values of the joint variables to ensure the motion system according to a given path are described. The conclusion is the last part.

\section{MATERIALS AND METHODS}

Consider the preliminary designed geostationary satellite monitoring antenna model as shown in Figure 1 and Figure 2. Accordingly, the mechanical system consists of two main parts which are the directional cluster and the satellite pan cluster (Figure 1). The movement of the rotating cluster is done by the rotating joint $q_{1}$ which is driven by motor 1 . The satellite pan cluster height is performed by rotating joint $q_{2}$. This joint is driven by motor 2 through the translational joint $\mathrm{A}$ and rotational joint $\mathrm{B}$. However, these joints are only responsible for driving the joint $q_{2}$, so it can be not considered in the kinematics problem. The center of the rotating cluster is $G_{1}$, the satellite pan assembly center is $G_{2}$. The kinematics model of the mechanical system can be constructed as shown in Figure 2.

Select a fixed coordinate system $(O X Y Z)_{0}$ attached to the ground. The $(O X Y Z)_{i},(\mathrm{i}=1 . .6)$ coordinate systems are respectively mounted at the positions shown in Figure 5. The above fixed and local coordinate systems are attached for the purpose of accurately determining the position of any point on the system. In particular, taking point $G_{2}$ is the end-effector point representing the satellite pan cluster and it is necessary to determine the position of this point according to the fixed coordinate system.

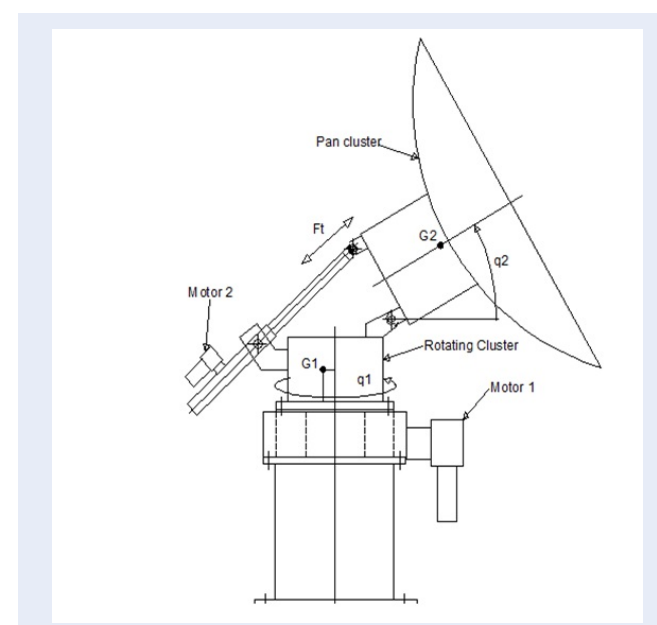

Figure 1: Preliminary mechanical system

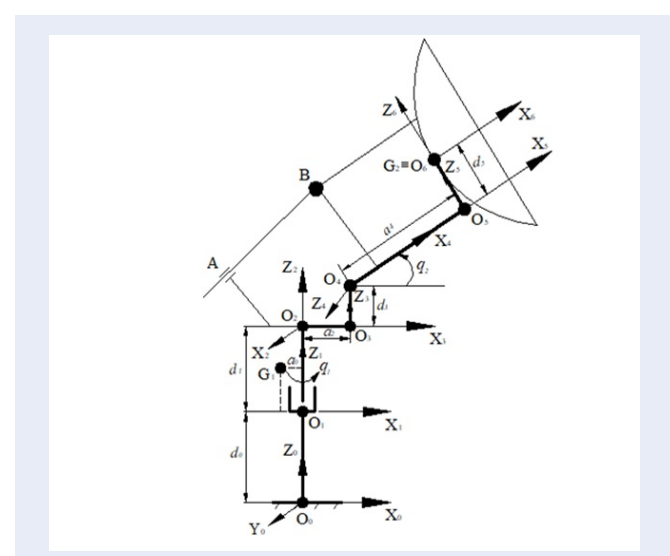

Figure 2: Kinematics diagram

Using the homogeneous matrix rotations and translations according to the D-H method ${ }^{13,14}$, the D-H pa- 
Table 1: D-H parameters

\begin{tabular}{lllll}
\hline Parameters & $\theta_{i}$ & $d_{i}$ & $a_{i}$ & $\alpha_{i}$ \\
$O_{0} O_{1}$ & 0 & $d_{0}$ & 0 & 0 \\
$O_{1} O_{2}$ & $q_{1}$ & $d_{1}$ & 0 & 0 \\
$O_{2} O_{3}$ & 0 & 0 & $a_{2}$ & 0 \\
$O_{3} O_{4}$ & 0 & $d_{3}$ & 0 & $\pi / 2$ \\
$O_{4} O_{5}$ & $q_{2}$ & 0 & $a_{4}$ & $-\pi / 2$ \\
$O_{5} O_{6}$ & 0 & $d_{5}$ & 0 & 0 \\
\hline
\end{tabular}

rameters tables can be described as shown in Table 1. Use the local homogeneous matrix as

$$
\begin{aligned}
& H_{i}= \\
& {\left[\begin{array}{cccc}
\cos \theta_{i} & -\sin \theta_{i} \cos \alpha_{i} & \cos \theta_{i} \sin \alpha_{i} & a_{i} \cos \theta_{i} \\
\sin \theta_{i} & \cos \theta_{i} \sin \alpha_{i} & \cos \theta_{i} \sin \alpha_{i} & a_{i} \sin \theta_{i} \\
0 & \sin \alpha_{i} & \cos \theta_{i} & d_{i} \\
0 & 0 & 0 & 1
\end{array}\right]}
\end{aligned}
$$

Matrix $H_{i}$ gives us information about the position of the $(O X Y Z)_{i}$ coordinate system compared to the $(O X Y Z)_{i-1}$ coordinate system. Accordingly, the local D-H matrices are presented as follows

$$
\begin{aligned}
& H_{1}=\left[\begin{array}{cccc}
1 & 0 & 0 & 0 \\
0 & 1 & 0 & 0 \\
0 & 0 & 1 & d_{0} \\
0 & 0 & 0 & 1
\end{array}\right] \\
& H_{2}=\left[\begin{array}{cccc}
\cos q_{1} & -\sin q_{1} & 0 & 0 \\
\sin q_{1} & \cos q_{1} & 0 & 0 \\
0 & 0 & 1 & d_{1} \\
0 & 0 & 0 & 1
\end{array}\right] \text {; } \\
& H_{3}=\left[\begin{array}{cccc}
1 & 0 & 0 & \alpha_{2} \\
0 & 1 & 0 & 0 \\
0 & 0 & 1 & 0 \\
0 & 0 & 0 & 1
\end{array}\right]
\end{aligned}
$$

And,

$$
\begin{aligned}
H_{4} & =\left[\begin{array}{cccc}
1 & 0 & 0 & 0 \\
0 & 0 & -1 & 0 \\
0 & 0 & 0 & d_{3} \\
0 & 0 & 0 & 1
\end{array}\right] ; \\
H_{5} & =\left[\begin{array}{cccc}
\cos q_{2} & 0 & -\sin q_{2} & a_{4} \cos q_{2} \\
\sin q_{2} & 0 & \cos q_{2} & a_{4} \sin q_{2} \\
0 & 0 & 1 & 0 \\
0 & 0 & 0 & 1
\end{array}\right] ; \\
H_{6} & =\left[\begin{array}{cccc}
1 & 0 & 0 & 0 \\
0 & 1 & 0 & 0 \\
0 & 0 & 1 & d_{5} \\
0 & 0 & 0 & 1
\end{array}\right]
\end{aligned}
$$

From local D-H matrices, the position of the $(O X Y Z)_{i}$ coordinate system compared to the fixed coordinate system $(O X Y Z)_{0}$ through matrix transformation ${ }^{14}$ can be determined as follows

$$
D_{i}=H_{1} H_{2} . . H_{i}, i=1 . .6
$$

Int which, matrix $D_{i}=\left[\begin{array}{cc}A_{3 \times 3} & P_{3 \times 1} \\ 0 & 1\end{array}\right]$ represents the position $\left(P_{3 \times 1}\right)$ and direction $\left(A_{3 \times 3}\right)$ of local coordinate systems relative to the fixed coordinate system. Specifically, the positions and directions of the coordinate systems are as follows

$$
\begin{aligned}
D_{1} & =\left[\begin{array}{cccc}
1 & 0 & 0 & 0 \\
0 & 1 & 0 & 0 \\
0 & 0 & 1 & d_{0} \\
0 & 0 & 0 & 1
\end{array}\right] ; \\
D_{2} & =\left[\begin{array}{cccc}
\cos q_{1} & -\sin q_{1} & 0 & a_{2} \cos q_{1} \\
\sin q_{1} & \cos q_{1} & 0 & a_{2} \sin q_{1} \\
0 & 0 & 1 & d_{0}+d_{1} \\
0 & 0 & 0 & 1
\end{array}\right]
\end{aligned}
$$

And,

$$
\begin{aligned}
D_{3} & =\left[\begin{array}{cccc}
\cos q_{1} & -\sin q_{1} & 0 & 0 \\
\sin q_{1} & \cos q_{1} & 0 & 0 \\
0 & 0 & 1 & d_{0}+d_{1} \\
0 & 0 & 0 & 1
\end{array}\right] \\
D_{4} & =\left[\begin{array}{cccc}
\cos q_{1} & 0 & \sin q_{1} & a_{2} \cos q_{1} \\
\sin q_{1} & 0 & -\cos q_{1} & a_{2} \sin q_{1} \\
0 & 0 & 1 & d_{0}+d_{1}+d_{3} \\
0 & 0 & 0 & 1
\end{array}\right]
\end{aligned}
$$

Following Figure 3

The position of $G_{2}$ point is determined according to the fixed coordinate system as follows

$$
\begin{aligned}
& x_{G 2}=\cos q_{1}\left(a_{2}+a_{4} \cos q_{2}-d_{5} \sin q_{2}\right) \\
& y_{G 2}=\sin q_{1}\left(a_{2}+a_{4} \sin q_{2}-d_{5} \sin q_{2}\right) \\
& z_{G 2}=d_{0}+d_{1}+d_{3}+a_{4} \sin q_{2}+d_{5} \cos q_{2}
\end{aligned}
$$

Operate an inspection at a number of special locations.

Position 1: $q_{1}=q_{2}=0$. This is the position where the direction cluster is in a stationary position. The centerline passes through the basin of the pan parallel to 
Then,

Finally,

$$
\mathbf{D}_{5}=\left[\begin{array}{cccc}
\cos q_{1} \cos q_{2} & -\sin q_{1} & -\cos q_{1} \sin q_{2} & \cos q_{1}\left(a_{2}+a_{4} \cos q_{2}\right) \\
\sin q_{1} \cos q_{2} & \cos q_{1} & -\sin q_{1} \sin q_{2} & \sin q_{1}\left(a_{2}+a_{4} \sin q_{2}\right) \\
\sin q_{2} & 0 & \cos q_{2} & d_{0}+d_{1}+d_{3}+a_{4} \sin q_{2} \\
0 & 0 & 0 & 1
\end{array}\right]
$$

$$
\mathbf{D}_{6}=\left[\begin{array}{cccc}
\cos q_{1} \cos q_{2} & -\sin q_{1} & -\cos q_{1} \sin q_{2} & \cos q_{1}\left(a_{2}+a_{4} \cos q_{2}-d_{5} \sin q_{2}\right) \\
\sin q_{1} \cos q_{2} & \cos q_{1} & -\sin q_{1} \sin q_{2} & \sin q_{1}\left(a_{2}+a_{4} \sin q_{2}-d_{5} \sin q_{2}\right) \\
\sin q_{2} & 0 & \cos q_{2} & d_{0}+d_{1}+d_{3}+a_{4} \sin q_{2}+d_{5} \cos q_{2} \\
0 & 0 & 0 & 1
\end{array}\right]
$$

Figure 3: Equation (7) and (8)

the axis $(O X)_{0}$ and parallel to the ground. We deduce: $x_{G 2}=a_{2}+a_{4} ; y_{G 2}=0 ; z_{G 2}=d_{0}+d_{1}+d_{3}+d_{5}$. This position is completely consistent with the kinematics model.

Position 2: $q_{1}=0, q_{2}=\frac{\pi}{2}$. This is the position of the satellite pan cluster with the centerline of the pan in the direction of vertical $(O Z)_{0}$. Now: $x_{G 2}=a_{2}-$ $d_{5} ; y_{G 2}=0 ; z_{G 2}=d_{0}+d_{1}+d_{3}+a_{4}$. This position is also completely suitable for the kinematics model. Thus, the results of the modeling of the system ensure reliability and accuracy.

\section{RESULTS AND DISCUSSION}

\section{The forward kinematics problem}

Apply with expected geometric parameters of the antenna to design and manufacture as follows $d_{0}=$ $3.62(m), d_{1}=0.87(m), a_{2}=0.39(m), d_{3}=0.2(m)$, $a_{4}=1.15(m), d_{5}=0.21(m)$. Limited joints: $0 \leq q_{1} \leq$ $2 \pi, 0 \leq q_{2} \leq \pi / 2$. The possible workspace of point $G_{2}$ is shown in Figure 5.

The forward kinematics problem is described with input is the law of variables of joints $q_{1}, q_{2}$ and the output is the motion law of point $G_{2}$ or any point on the system in workspace including position, velocity, and acceleration. this problem can be solved by using the MATLAB calculation software according to the diagram in Figure 6.

The given law of variables joints is $q_{1}=\pi t / 5, q_{2}=$ $\pi / 4$. The coordinate $z_{G 2}$ is constant, the trajectory of $G_{2}$ point is a circle parallel to plane $(O X Y)_{0}$.

The input of the forward kinematics problem is the law of the joint variables and is shown in Figure 6. The results of this problem analysis are shown in Figure 7 to Figure 10. The position of point $G_{2}$ is shown in Figure 7 . The maximum value along the $(O Z)_{0}$ axis is $5.68(\mathrm{~m})$, the $(O X)_{0}$ and $(O Y)_{0}$ reaches $1(\mathrm{~m})$. Figure 8 and Figure 9 show the velocity and acceleration of point $G_{2}$, respectively. The point path of the $G_{2}$ point in the $(O X Y)_{0}$ plane is shown in Figure 10.

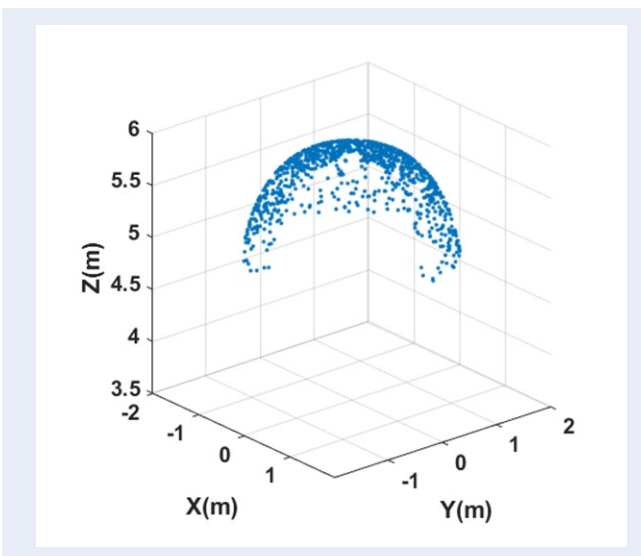

Figure 4: The possible workspace $G_{2}$

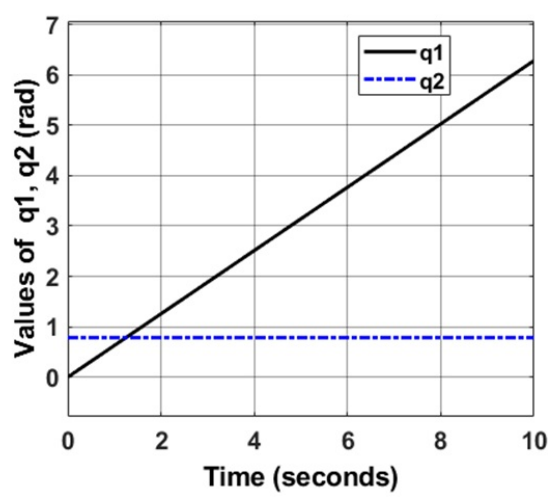

Figure 6: The law of variable joints

\section{The inverse kinematics problem}

The inverse kinematics problem is described with input as the desired path of the end-effector point $G_{2}\left(x_{G 2}, y_{G 2}, z_{G 2}\right)$ in the workspace and the output as the law of the joints variables that satisfy the required input trajectory. The inverse kinematics prob- 


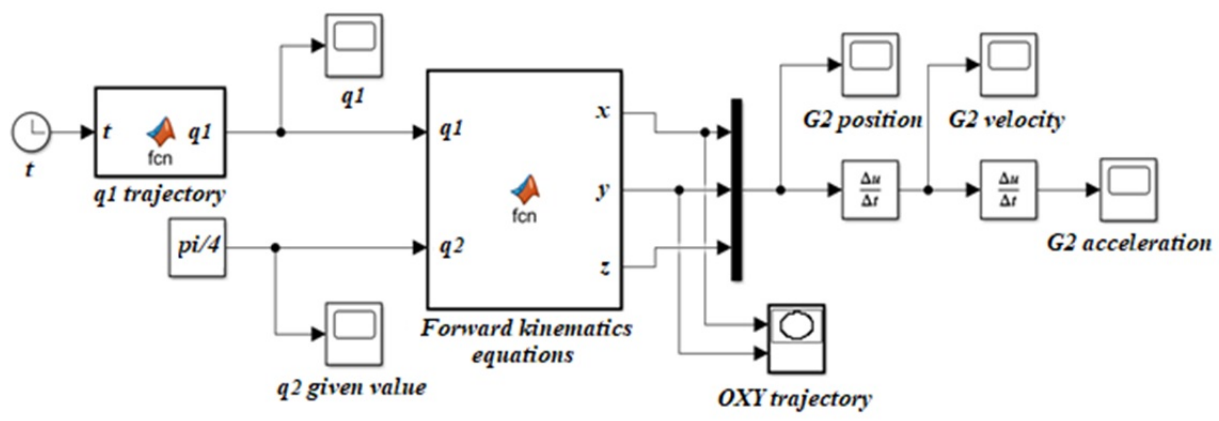

Figure 5: Forward kinematics calculation diagram

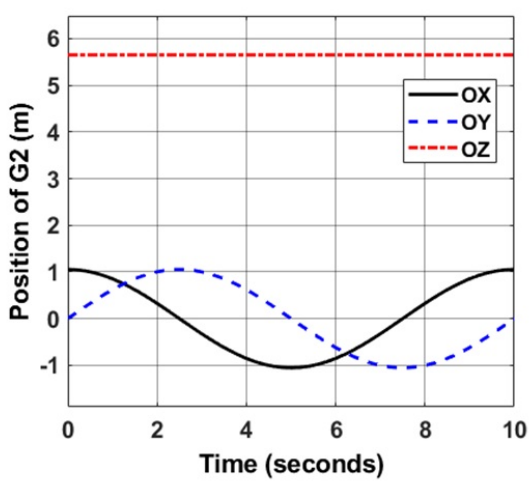

Figure 7: Position of $G_{2}$ point

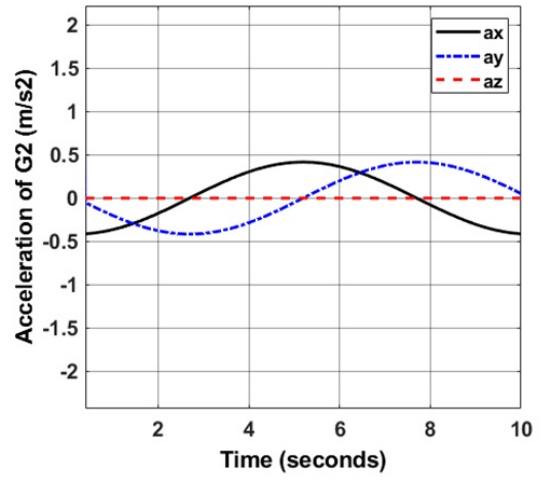

Figure 9: Acceleration of $G_{2}$ point

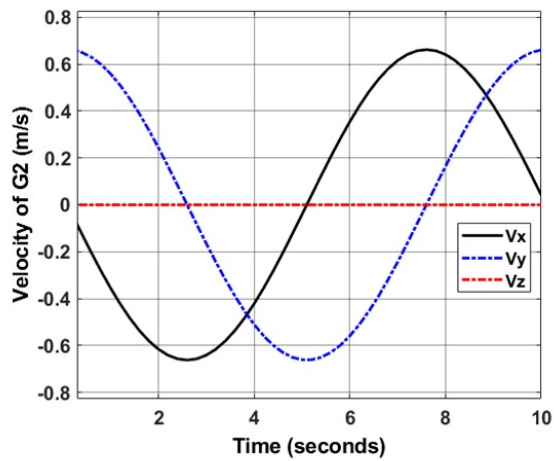

Figure 8: Velocity of $G_{2}$ point

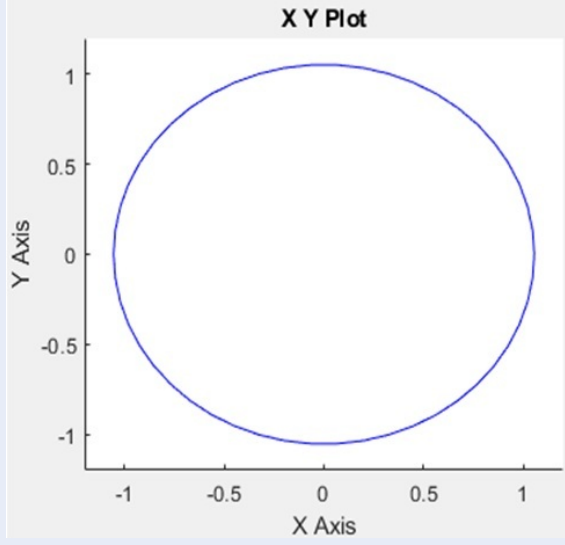

Figure 10: The path of $G_{2}$ on the $(O X Y)_{0}$ 
lem can be solved using either the analytical method or the numerical method. On the one hand, the analytic method allows us to use the kinematics equation transforms (9) to find $q_{1}, q_{2}$. However, the solving process will encounter transcendent trigonometric functions, so there are many satisfying results. The problem of choosing the right answer to the system configuration is not a simple problem and takes a lot of time. Sometimes this approach is not feasible for complex systems. On the other hand, the numerical method uses modern algorithms to solve problems according to the approximation method. The outstanding advantage of this method is the feasibility and response to the requirements of the system configuration, which can solve complex problems that the analytical method cannot meet. The limitations of the numerical method are errors. However, with the strong development of computer science and mathematics, this problem is almost completely solved compared to the requirement of the problem. The algorithm of adjusting the generalized vector ${ }^{14-17}$ is applied to solve this problem.

To facilitate the presentation of the generalized problem, some vectors are defined as follows

$$
\begin{aligned}
& x(t)=\left[\begin{array}{lll}
x_{G 2} & y_{G 2} & z_{G 2}
\end{array}\right]^{T} ; \\
& q(t)=\left[\begin{array}{lll}
q_{1} & q_{2} & q_{n}
\end{array}\right]^{T}
\end{aligned}
$$

Relationship between coordinates of $G_{2}$ point in the workspace and joints coordinates in the joint space can be described as follows

$$
x=f(q)
$$

The derivative of the two-sided derivative (11) respect to time

$$
\dot{x}=\frac{\partial f}{\partial q} \dot{q}=J(q) \dot{q}
$$

where,

$$
J(q)=\frac{\partial f}{\partial q}=\left[\begin{array}{cccc}
\frac{\partial f_{1}}{\partial q_{1}} & \frac{\partial f_{1}}{\partial q_{2}} & \ldots & \frac{\partial f_{1}}{\partial q_{n}} \\
\ldots & \ldots & \ldots & \ldots \\
\frac{\partial f_{3}}{\partial q_{1}} & \frac{\partial f_{3}}{\partial q_{2}} & \ldots & \frac{\partial f_{3}}{\partial q_{n}}
\end{array}\right]
$$

The matrix J(q) of size $3 \mathrm{xn}$ is called a Jacobi matrix. For the redundant system, it is common to choose the pseudo-inverse matrix of the rectangular matrix J(q) as

$$
J^{+}(q)=J^{T}(q)\left[J(q) J^{T}(q)\right]^{-1}
$$

Then from the expression (14), the joints velocity is determined as

$$
\dot{q}(t)=J^{+}(q) \dot{x}(t)
$$

The derivative of the two-sided derivative (12) respect to time

$$
\ddot{x}(t)=J(q) \ddot{q}(t)+\dot{J}(q) \dot{q}(t)
$$

From (16)

$$
J(q) \ddot{q}(t)=\ddot{x}(t)-\dot{J}(q) \dot{q}(t)
$$

Put (15) into (17)

$$
J(q) \ddot{q}(t)=\ddot{x}(t)-\dot{J}(q) J^{+}(q) \dot{x}(t)
$$

Then the joints acceleration vector can be written as

$$
\ddot{q}(t)=J^{+}(q) \ddot{x}(t)-J^{+}(q) \dot{J}(q) J^{+}(q) \dot{x}(t)
$$

The velocity and acceleration vectors can be calculated from Eq. (15) and Eq. (19) if know q(t) at the time of investigation and $x(t), \dot{x}(t), \ddot{x}(t)$.

Consider the desired motion of point $G_{2}$ as follows

$$
\begin{aligned}
x_{G 2} & =\cos \frac{\pi}{4} t(m) ; \\
y_{G 2} & =\sin \frac{\pi}{4} t(m) ; \\
z_{G 2} & =5.68(m)
\end{aligned}
$$

Operate the inverse kinematics problem in MATLAB software, the results of this problem are described in Figure 11 to Figure 16. The values of variables joints are shown in Figure 11. The joints errors are presented in Figure 12. The velocity and acceleration of joints also described in Figure 13 and Figure 14, respectively. The position of end-effector point $G_{2}$ can be recalculated through the forward kinematics equations with received $\mathrm{q}(\mathrm{t})$ is shown in Figure 15 with small position error which is presented in Figure 16. The 3D model of antenna system (Figure 17) can be simulated in the MATLAB software by using the results of the inverse kinematics problem.

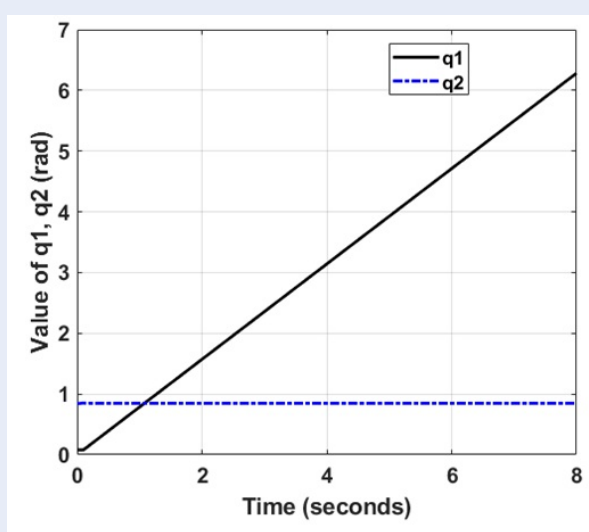

Figure 11: The positions of joints 


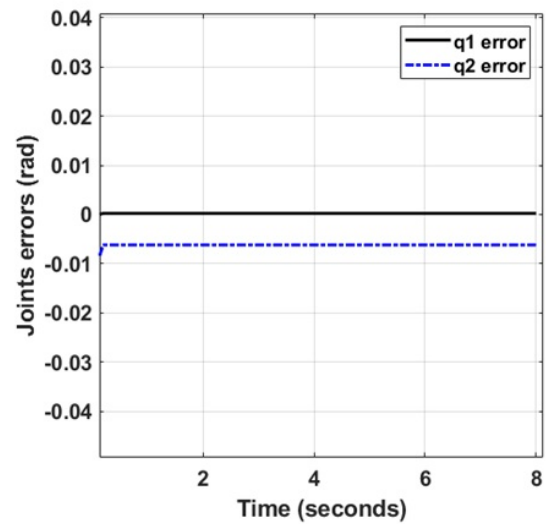

Figure 12: The joints errors

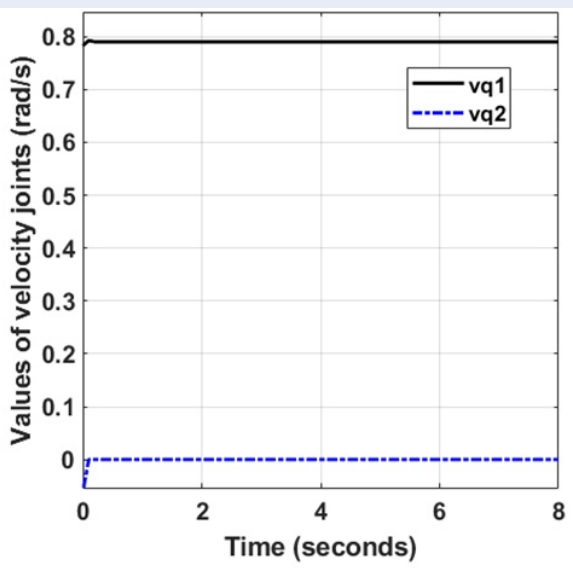

Figure 13: The joints velocities

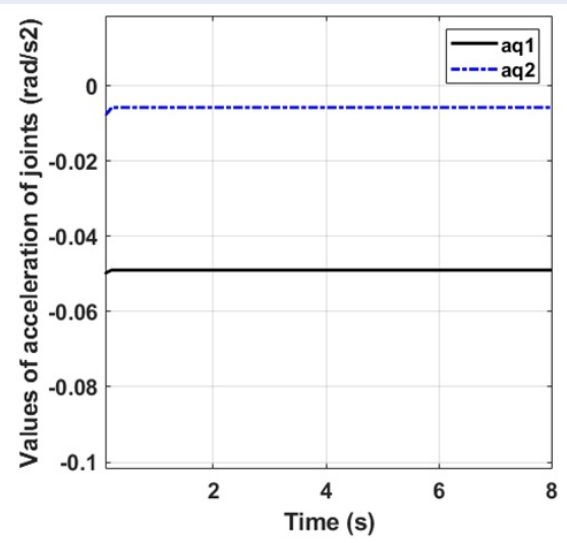

Figure 14: The joints accelerations

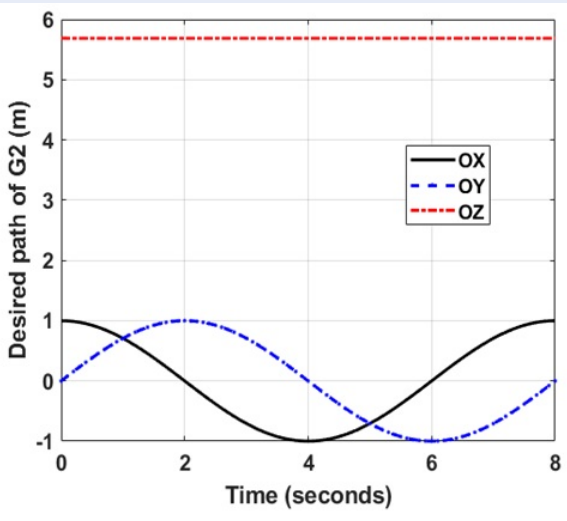

Figure 15: The position of $G_{2}$ point

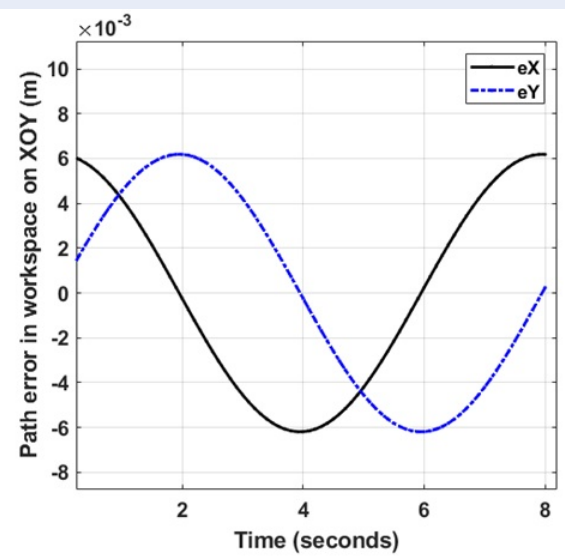

Figure 16: The position error of $G_{2}$

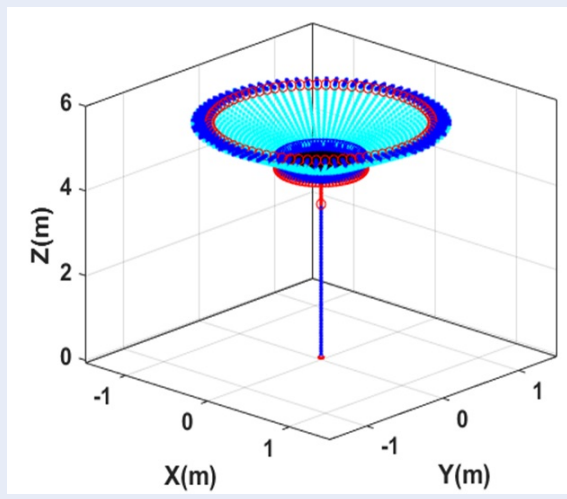

Figure 17: The motion trajectory of point $G_{2}$ in MATLAB 
The dynamics equation and control system problems has been built and solved based on the results of the kinematics modeling analysis above. Figure 18 shows the entire antenna system fabricated and is in the process of assembly. The details of this issue will be presented in the next studies in the near future.
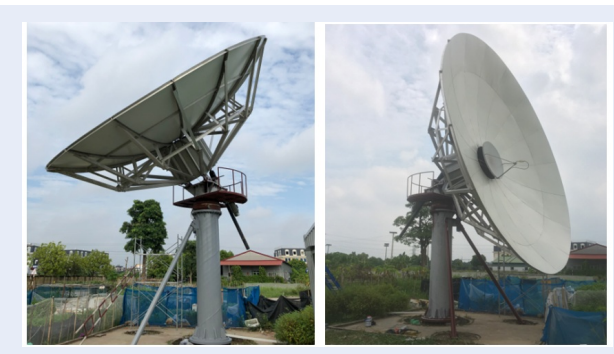

Figure 18: Geostationary satellite surveillance antenna was fabricated

\section{CONCLUSIONS}

In conclusion, this paper presents the kinematics modeling of antenna systems for geostationary satellite communications and monitoring, with the focus on analyzing the kinematics problems. The workspace, position, velocity and acceleration of the pan cluster center of mass are calculated by using the limit value of joints and solving the forward kinematics problem. The rules of joints are determined ensuring the given trajectory of pan cluster center of mass in the workspace through analyzing the inverse kinematics problem. The numerical simulation results kinematics were successfully applied in dynamics and control analyzing and in practice.

\section{CONFLICT OF INTEREST}

All of authors have no conflict on interest in publishing of the paper

\section{AUTHOR CONTRIBUTION}

Quoc-Hoang PHAM proposed ideas, research methods, quality monitoring and correcting the manuscript. Xuan-Hung LE, Manh-Tung DO, Tai-Hoai Thanh NGUYEN, Hong-Phong NGUYEN, Van-Tuan PHAM, and Tien-Trung VUONG designed and fabricated the system. Xuan-Bien
DUONG implemented research methods, calculated the program and drafted the manuscript.

\section{REFERENCES}

1. Maral G. Satellite communications systems - Systems, Techniques and Technology, Fifth Edition. John Wiley and Sons, Ltd Publication. 2009;.

2. Satcom and Antenna technologies division at www.cpii.com [Access: October 2020];.

3. Vincor ${ }^{\mathrm{TM}}$ Product Data and Specification Archives: www.catal og.vincor.com [Access: October 2020];

4. Hubble Space Telescope: www.nasa.gov [Access: October 2020];:

5. Featured SATCOM Products: www.satcom-services.com [Access: October 2020];

6. Antenna Systems: www.viasat.com/products/antenna-syste ms [Access: October 2020];

7. Satellite Communications equipment: www.digisat.org [Access: October 2020] ;.

8. Bindi Y, Dong L. Dynamics analysis and control of a spacecraft mechanism with joint clearance and thermal effect. Precision Motion Systems: Modeling, Control, and Applications, Elsevier Inc. 2019;p. 163-215. Available from: https://doi.org/10. 1016/B978-0-12-818601-5.00017-2.

9. Ogundele DA, et al. Mathematical Modelling of Antenna Look Angles of Geostationary Communications Satellite Using Two Models of Control Stations, 3rd International Conference on Advanced Computer Theor and Engineering (ICACTE). 2010;p. 236-240.

10. Ogundele DA, et al. Model validation and analysis of antenna look angles of a geostationary satellite, International Conference on Computer Science and Automation Engineering (CSAE), IEEE. 2012;p. 509-513. Available from: https://doi. org/10.1109/CSAE.2012.6272824.

11. Lida T. Satellite Communications Antenna Concepts and Engineering, Handbook of Satellite Applications, Springer Science+Business Media New York. 2015;PMID: 25435485. Available from: https://doi.org/10.1007/978-1-4614-6423-5_18-3.

12. Shankar SG, Reddy KV. Design and Simulation of Horn Antenna in $\mathrm{x}-\mathrm{Ku}$ Band for Satellite Communications. International Journal of Research in Science \& Technology (IJRST). 2014;1(10).

13. Spong MW, Hutchinson S, Vidyasagar M. Robot modeling and Control, First edition. New York, USA. 2001;

14. Khang NV. Dynamics of Multi-bodies. Hanoi Science and Technology Publishing House. 2007;.

15. Khang NV, et al. Inverse kinematic and dynamic analysis of redundant measuring manipulator BKHN-MCX-04. Vietnam Journal of Mechanics, VAST. 2010;32:15-26. Available from: https://doi.org/10.15625/0866-7136/32/1/313.

16. My CA, et al. Inverse Kinematics Analysis of Welding Robot IRB 1520ID Using Algorithm for Adjusting the Increments of Generalized Vector. The 5th International Conference on Research in Intelligent and Computing in Engineering. Springer Singapore. 2020;Available from: https://doi.org/10.1007/978981-15-7527-3.

17. Bien DX, et al. Optimize the Feed Rate and Determine the Joints Torque for Industrial Welding Robot TA 1400 Based on Kinematics and Dynamics Modeling, International Journal of Mechanical Engineering and Robotics Research (IJMERR). 2020;9(9):1335-1340. Available from: https://doi.org/10. 18178/ijmerr.9.9.1335-1340. 


\title{
Phân tích mô hình động học hệ thống Anten giám sát vệ tinh địa tĩnh
}

\author{
Phạm Quốc Hoàng, Lê Xuân Hùng, Đỗ Mạnh Tùng, Nguyễn Tài Hoài Thanh, Nguyễn Hồng Phong, \\ Vương Tiến Trung, Phạm Văn Tuân, Dương Xuân Biên*
}

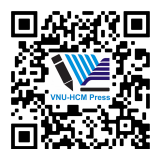

Use your smartphone to scan this QR code and download this article

Trung tâm Công nghê, Đai hoc Kỹ thuât Lê Quý Đôn, 236 Hoàng Quốc Việt, Bắc Tư Liêm, Hà Nội, Việt Nam

Liên hệ

Dương Xuân Biên, Trung tâm Công nghệ, Đại học Kỹ thuật Lê Quý Đôn, 236 Hoàng Quốc Việt, Bắc Từ Liêm, Hà Nội, Việt Nam

Email: duongxuanbien@lqdtu.edu.vn

Lịch sử

- Ngày nhận: 19-09-2020

- Ngày chấp nhận: 05/03/2021

- Ngày đăng: 15/03/2021

DOI : 10.32508/stdjet.v4i1.770

\section{Check for updates}

\section{Bản quyền}

๑ Đ ĐHQG Tp.HCM. Đây là bài báo công bố mở được phát hành theo các điều khoản của the Creative Commons Attribution 4.0 International license.

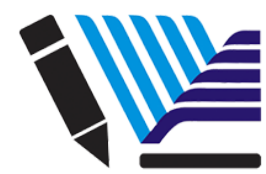

VNU-HCM Press

\section{TÓM TẮT}

Xu hướng phát triển khoa học trong tương lai không thể không kể đến sức ảnh hưởng to lớn của lĩnh vực không gian vũ trụ, trước mắt là các hệ thống vệ tinh liên quan đến công nghệ viễn thông. Trên thực tế, ở một số nước có nền công nghệ thông tin liên lạc và công nghệ vũ trụ phát triển mạnh mẽ thì vấn đề thiết kế, chế tạo hệ thống cơ khí anten giám sát vệ tinh địa tĩnh chắc chắn đã được giải quyết triệt để. Tuy nhiên, vì là một công nghệ đặc thù nên việc chia sẻ và chuyển giao công nghệ thiết kế và chế tạo cho các nước đang phát triển không hề dễ dàng. Hầu như rất khó tìm thấy các công trình đã công bố liên quan đến tính toán thiết kế cơ khí và chế tạo hệ thống anten giám sát vệ tinh địa tĩnh. Vấn đề chủ động nắm bắt công nghệ, từng bước tự chủ công nghệ chế tạo thiết bị viễn thông liên quan đến công nghệ vũ trụ luôn là mục tiêu của các nước đang phát triển như Việt Nam quan tâm và hướng tới nhằm hạn chế sự phụ thuộc công nghệ, giảm thiểu chi phí trang bị, chuyển giao công nghệ, đảm bảo bí mật quốc gia. Bước đầu tiên trong những vấn đề này là việc chủ động tự nghiên cứu thiết kế và chế tạo các thiết bị thu phát trên mặt đất như anten giám sát vệ tinh địa tĩnh.

Bài báo này trình bày việc phân tích mô hình động học cho hệ thống anten giám sát vệ tịnh địa tĩnh. Mỗi thành phẩn của hệ thống anten được giả thiết là vật rắn tuyệt đối. Mô hình toán học được xây dựng dựa trên lý thuyết động học và động lực học hệ nhiều vật. Phương pháp ma trận chuyển đổi thuần nhất DENAVIT-HARTENBERG (D-H) được sử dụng để xây dựng các phương trình động học. Bài toán động học thuận được phân tích để xác định vị trí, vận tốc, gia tốc và không gian làm việc của hệ thống anten với các giới hạn chuyển động góc của hệ thống đã cho. Bài toán động học ngược được đề cập để xác định các ứng xử động học của hệ thống anten với quỹ đạo chuyển động cho trước trong không gian làm việc. Kết quả tính toán và mô phỏng số động học đã được ứng dụng thành công trong thực tế, đặc biệt là ứng dụng để phân tích bài toán động lực học và bài toán điều khiển cho hệ thống anten vệ tinh địa tĩnh.

Từ khoá: Vệ tinh địa tĩnh, hệ thống anten, mô hình hóa, động học
Trích dẫn bài báo này: Hoàng $P Q$, Hùng $L X$, Tùng $D M$, Thanh $N T H$, Phong $N H$, Trung $V T$, Tuân $P V$, Biên $D X$. Phân tích mô hình động học hệ thống Anten giám sát vệ tinh địa tĩnh. Sci. Tech. Dev. J. Eng. Tech.; 4(1):705-713. 